\title{
DIFFERENTIAL HISTOMORPHOMETRIC CHANGES IN NORMAL AND INFLAMED GINGIVAL EPITHELIUM
}

\author{
Tanaskovic Stankovic Sanja, ${ }^{1}$ Cabunac Jovan, ${ }^{2}$ Kanjevac Tatjana, ${ }^{2}$ Milosavljevic Zoran ${ }^{1}$ \\ ${ }^{1}$ Histology and embryology Institute, Faculty of Medical Sciences, \\ University of Kragujevac, Serbia \\ ${ }^{2}$ Department for Preventive and Pediatric Dentistry, Faculty of Medicine, \\ University of Kragujevac, Serbia
}

Primljen/Received 13. 06. 2016. god.

Abstract: Introduction and aim: In recent decades, many factors such as smoking, unhealthy diet as well as high alcohol intake were marked as risk factors that can lead to increased incidence of malignant alterations, gingivitis, periodontal disease and other oral epithelium pathological changes. Having in mind that in the group of non-malignant and non-dental oral pathology gingivitis and periodontal disease are the most common oral mucosa alterations aim of our research was to investigate histomorphometric characteristics of healthy and altered oral and gingival epithelium.

Material and methods: Tissue samples of 24 oral and gingival mucosa specimens were collected. Samples were fixed in $10 \%$ buffered paraformaldehyde, routinely processed and embedded in paraffin blocks. From each block sections 5 micrometer thin were made and standard H/E staining as well as immunocytochemical detection of Ki-67 proliferation marker and CD79a lymphocyte marker were performed. Measurements and image analysis was performed with Image Pro Plus software (Media Cybernetics, USA) and Axiovision (Ziess, USA).

Results: We showed that inflamed gingival epithelium is increasing its thickness in proportion to the severity of adjacent inflammation. Furthermore, mitotic index is rising (up to $132 \%$ ) in the same manner as well as basal lamina length (up to $70 \%$ ) when normal and inflamed gingiva is compared. Architecture of epithelial ridges is changed from straightforward to mesh-like.

Conclusion: Assessment of the free gingival epithelium thickness is directly related to the severity of the inflammation process in gingiva.

Keywords: histomorphometry, gingiva, Ki-67, gingivitis.
Prihvaćen/Accepted 16. 07. 2016. god.

\section{INTRODUCTION}

Oral epithelium belongs to the stratified squamous type, with or without keratinization. Although one name is used for the whole epithelial lining of the mouth, there are several subtypes of this tissue, according to their specific site (1). Relatively quick turnover rate of this epithelium and exposure to various agents makes it vulnerable and susceptible for disease onset (2, $3)$. In recent decades, many factors such as smoking, unhealthy diet as well as high alcohol intake were marked as risk factors that can lead to increased incidence of malignant alterations, gingivitis, periodontal disease and other oral epithelium pathological changes $(4,5$, 6). World health organization statistical data shows that periodontal disease is found in $15-20 \%$ middle aged adults while the incidence of oral cancer ranges from one to 10 cases per 100000 people in most countries (5). Furthermore, it is well established fact that oral diseases in children and adults are higher among poor, older and disadvantaged population groups (2). Review of literature reveals that, for many of oral diseases, among the first changes there is an alteration of the morphometric characteristics of the oral epithelium $(3,4)$. Pejcic et al. (7), Villar et al. (8) and Bulut et al. (9) reported that smoking and Cyclosporine A-induced inflammation affects thickness of oral and gingival epithelium as well as degree of the keratinization while Birajdar et al. (10) stated that expression of keratinocyte proliferative marker is a significant prognostic factor for the oral leukoplakia and oral squamous cell carcinoma. Having in mind that in the group of non-malignant and non-dental oral pathology gingivitis and periodontal disease are the most common oral mucosa alterations and the fact that changes of epithe- 
lial tissue are, in many cases, the first sign of oral pathology, the goal of our research was to thoroughly investigate histomorphometric characteristics of healthy and altered oral and gingival epithelium such as overall thickness, basal cell count as well as mitotic index of the basal keratinocytes.

\section{MATERIALS AND METHODS}

Tissue samples of 24 oral and gingival mucosa specimens (14 male and 10 female, aged from 42-67 years) were collected during the various dentistry procedures at the Department for Preventive and Pediatric Dentistry from September 2015 through March 2016. Ethical approval for the research protocol was issued by Ethics Committee of the Dentistry Department, Health Centar Kragujevac. All patients were fully informed and gave their consent. Histomorphometric analysis was performed at the Histology Institute, Faculty of Medical Sciences, Kragujevac. Specimens were divided into three groups: normal buccal mucosa, normal gingiva and inflamed gingival according to the clinical status. All tissue samples were fixed in $10 \%$ buffered paraformaldehyde for 24 hours, routinely processed and embedded in paraffin blocks. From each block sections 5 micrometer thin were made and standard H/E staining as well as routine immunocytochemical staining of the Ki-67 proliferation marker and CD79a lymphocyte marker were performed. Staining for Ki-67 and CD79a was performed with a streptavidin-biotin (SAB) complex method using the Histofine SAB-PO kit (Nichirei Co., Tokyo, Japan) according to the manufacturer's directions. Images of tissue sections were captured with digital camera attached to the Olympus BX51 microscope. Measurements of the epithelial thickness, ridges length and basal lamina/epithelial surface length (BLL/ESL) were perfor- med with Axiovision (Ziess, USA) and Image Pro Plus software (Media Cybernetics, USA). Mitotic index was assessed by two independent researchers marking the number of the dividing basal keratinocytes. Results were presented as mean \pm SD. Statistical analysis was done using the SPSS software. Estimation of statistical significance between mean values was performed with student T-test. Level of significance was set at $\mathrm{p}<0.005$.

\section{RESULTS}

Based on the histopathological features, in our series, 8 samples were characterized as normal buccal mucosa, 6 samples as a normal gingival mucosa and 10 samples as inflamed gingival mucosa from which 6 specimens were marked as mild gingivitis and 4 cases as a severe gingivitis. The degree of lymphocyte infiltration (assessed by virtue of immunochemical staining) was the determining factor for the classification of the gingivitis-affected samples. Normal buccal mucosa showed classic characteristics of non-keratinized stratified squamous epithelium. Overall thickness of this epithelium was $396 \pm 41 \mu \mathrm{m}$ while epidermal ridges comprised just $89.88 \pm 7 \mu \mathrm{m}$. Basal lamina length was $133 \%$ larger than epithelial surface length (BLL/ESL). Immunochemical detection of Ki-67 antigen showed that percentage of dividing basal cells was $7.1 \pm 1.6$. Healthy gingival oral epithelium showed mild orthokeratinization. Overall thickness of this epithelium was $478 \pm 27 \mu \mathrm{m}$, while epidermal ridges comprised significant $251 \pm 38 \mu \mathrm{m}$. BLL/ESL ratio was $305 \%$. Percentage of dividing cells was $8.0 \pm$ 0.6. Tissue specimens with mild gingivitis showed orthokeratinization very similar to the healthy gingiva. Overall epithelium thickness was $508 \pm 27 \mu \mathrm{m}$, while pretty strait epidermal ridges (Figure 1a) comprised $351 \pm 58 \mu \mathrm{m}$. BLL/ESL ratio was 504\%. Per-

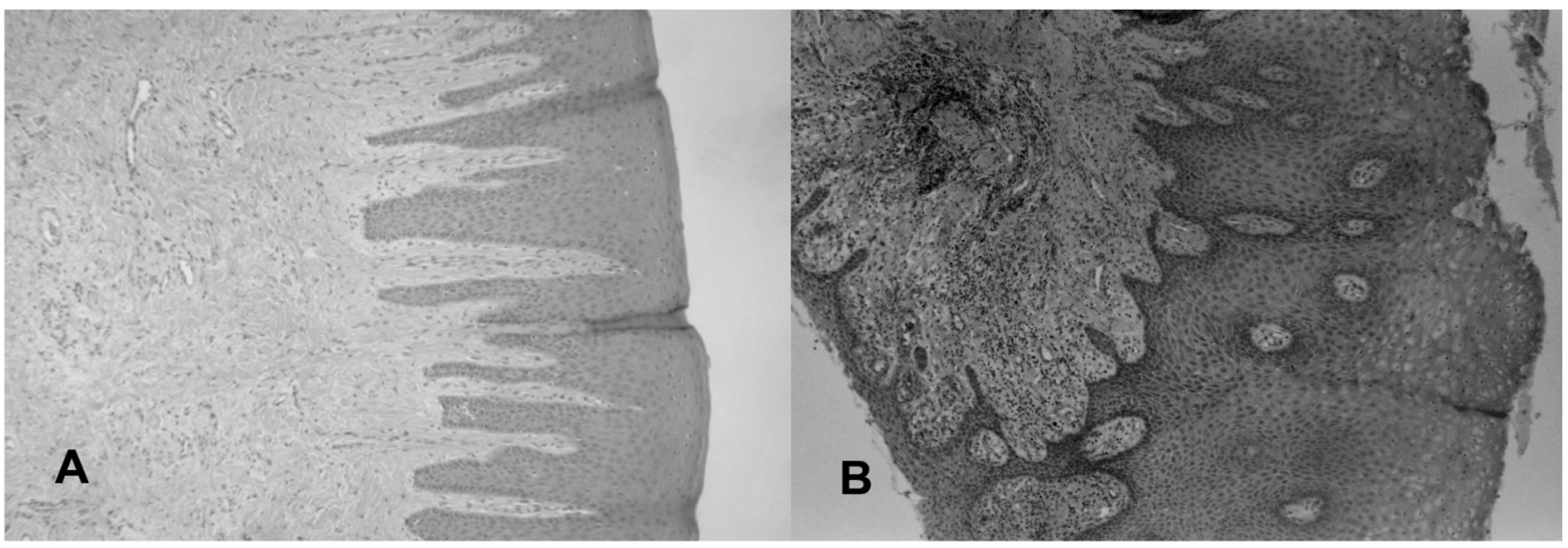

Figure 1. Epithelial ridges architecture in normal (A) and severe gingivitis (B) cases. Fig $B$ showing the complex epithelial ridges structure (H/E staining, magnification x100) 
Table 1. Histomorphometric epithelial measurement data

\begin{tabular}{|c|c|c|c|c|}
\hline & $\begin{array}{c}\text { Ep. } \\
\text { Thickness } \\
(\mu \mathrm{m})\end{array}$ & $\begin{array}{c}\text { Ridges } \\
\text { length } \\
(\mu \mathrm{m})\end{array}$ & $\begin{array}{c}\text { BLL/ESL } \\
\text { ratio } \\
(\%)\end{array}$ & $\begin{array}{c}\text { Mitotic } \\
\text { index }\end{array}$ \\
\hline $\begin{array}{c}\text { Normal } \\
\text { buccal }\end{array}$ & $396 \pm 41$ & $90 \pm 7$ & 133 & $7.1 \pm 1.6$ \\
\hline $\begin{array}{c}\text { Normal } \\
\text { gingival }\end{array}$ & $478 \pm 27$ & $251 \pm 38$ & 305 & $8.0 \pm 0.6$ \\
\hline $\begin{array}{c}\text { Mild } \\
\text { gingivitis }\end{array}$ & $508 \pm 27$ & $351 \pm 58$ & $504^{*}$ & $8.7 \pm 0.5$ \\
\hline $\begin{array}{c}\text { Severe } \\
\text { gingivitis }\end{array}$ & $581 \pm 23^{*}$ & - & 355 & $9.4 \pm 0.3^{*}$ \\
\hline
\end{tabular}

centage of dividing basal keratinocytes was similar to the healthy gingival epithelium $(8.7 \pm 0.5 \%)$. Severe gingivitis (edging the periodontal disease), in our series, led to increased overall thickness of free gingival epithelium compared to normal and mild cases. Furthermore, keratinization process was altered and layer of orthokeratinized cells on the surface of the epithelium was disrupted and somewhere almost missing. Average thickness was $581 \pm 23 \mu \mathrm{m}$ while epithelial ridges showed complex intertwined pattern (Figure 1b) which prevented us to precisely assess its morphometric features. The same thing happened when BLL/ESL ratio was measured. Our results showed that this ratio was $355 \%$ but, again, due to complex epithelial ridge-dermal papillae architecture values must be interpreted carefully. The percentage of dividing basal cells was significantly higher than in normal, but insignificantly compared to the mild gingivitis cases $(9.4 \pm 0.3 \%)$. All measurements were presented in Table 1 where statistical significance compared to normal tissue was marked with asterisk (*). Hence, our study showed that thickness of the epithelium and mitotic index in severe gingivitis cases were significantly higher than in normal mucosa, while basal lamina length to epithelium surface length was significantly higher in mild gingivitis cases compared to control.

\section{DISCUSSION}

According to the WHO statistical data, incidence of the diseases of oral mucosa is increasing (5). This is mostly due to exposure to the risk factors such as unhealthy diet, smoking, alcohol intake as well as increased average age of the human population $(6,11,12)$. In the group of non-malignant oral mucosa-related diseases, inflamed gingiva and periodontal disease is the most common (6) but, although whole-thickness oral mucosa is affected, the main changes are located in epidermal layer. Furthermore, the first signs of gingiva-related diseases are also in squamous stratified epithelium as proved in study of Prakash P et al. (13). These signs include morphometric features such as epithelial thickness, layer representation, epidermal ridges length and architecture as well as mitotic index of the basal keratinocytes. Available literature data concerning histomorphometry of normal and inflamed oral and gingival epithelium shows that mild inflammation causes epithelium thickening, and severe ones induce epithelial thinning $(2,8)$. Nevertheless, plethora of these data is related solely to the junctional and sulcar part of the gingival epithelium, but there are very scarce results concerning marginal gingival epithelium characteristics. Our study was designed to reveal changes only in this specific tissue. For the verification of the degree of inflammation we used immunocytochemistry staining with antibody raised against CD79a antigen. We showed that marginal gingival epithelium is increasing its thickness in proportion to the severity of adjacent inflammation. This finding is in a collision with results of Lukandu (14), but their findings are related to the sulcar, not marginal epithelium. In our study mitotic index of basal keratinocytes is rising in the same manner as proved in our study by immunostaining against the Ki-67 antigen. This is similar to the findings of Bulut et al. (9). In their study on cyclosporin-A induced gingivitis they stated that the number of PCNA labeled mitotic cells raises two-fold in gingivitis compared to normal gingival. Our results also showed increased number of dividing basal cells but the degree is much smaller (about 18\%). Tissue specimens with severe gingivitis in our study showed altered epidermal ridges architecture. In normal gingiva and mild gingivitis cases ridges were prominent and numerous, but with straightforward manner in the lamina propria. In severe cases (bordering periodontal disease) ridges showed mesh-like structure with significant basal lamina length. This fact is important because the length of the basal lamina is directly related to the overall number of basal cells that participate in epithelium renewal e.g. the longer the basal lamina bellow the epithelium surface, greater is the number of the basal cells that can enter mitosis. This fact can be a good explanation for the thickening, not the thinning of the marginal epithelium. Having in mind previously mentioned facts our study clearly showed that distant inflammation significantly affects morphometric features of the marginal gingival epithelium. Although changes of sulcar and junctional gingival epithelium are thought to be more important for the clinical expression of inflamed gums and periodontal disease, signs of morphometric changes of oral side should be carefully esti- 
mated. This is important because, as shown by Prestin $\mathrm{S}$ et al. (15), by virtue of OCT (Optical Coherence Tomography), relatively novel method in dentistry, epithelial thickness can be assessed with ease and the most accessible spot for this analysis is free gingival epithelium. Having in mind that precise estimation of the depth and severity of the inflammation process in gingiva is still a significant clinical problem in dentistry, we think that our findings, combined with possibilities of the OCT will bring a novel approach for the assessment of the severity of the gingival inflammation process.

\section{Conflict of interest}

The authors declare that there is no conflict of interest.
Abbreviations
$\mathbf{H} / \mathbf{E}$ - Hematoxylin /eosin
WHO - World health organization
ESL - Epithelial surface length
BLL - Basal lamina length
PCNA - Proliferating cell nuclear antigen
OCT - Optical Coherence Tomography

\title{
Sažetak
}

\section{HISTOMORFOMETRIJSKE PROMENE EPITELA KOD NORMALNE I INFLAMIRANE GINGIVE}

\author{
Tanasković Stanković Sanja, ${ }^{1}$ Cabunac Jovan, ${ }^{2}$ Kanjevac Tatjana, ${ }^{2}$ Milosavljević Zoran ${ }^{1}$ \\ ${ }^{1}$ Institut za Histologiju i embriologiju, Fakultet medicinskih nauka Kragujevac, Srbija \\ ${ }^{2}$ Katedra za preventivnu i dečiju stomatologiju, Fakultet medicinskih nauka, \\ Univerzitet u Kragujevcu, Kragujevac, Srbija
}

Uvod i cilj: U poslednjim decenijama su pušenje, nezdrava ishrana i konzumiranje alkohola doveli do povećane incidence bolesti usne duplje kao što se kanceri, gingivitis, parodontopatija i dr. Imajući u vidu da su van grupe malignih bolesti i oboljenja zuba gingivitis i parodontopatija najučestalije bolesti usne duplje, mi smo želeli da uporedimo histomorfometrijske karakteristike normalnog i obolelog epitela bukalne sluznice i slobodne gingive, kao i gingive zahvaćene blažim i težim formama zapaljenja.

Materijal i metode: Uzorci tkiva normalne oralne sluznice i obolele gingive su uzeti od 24 pacijenta. Tkivo je fiksirano u paraformaldehidu, rutinski histološki obrađeno i kalupljeno u parafinske blokove. Isečci debeli 5 mikrometara su bojeni $\mathrm{H} / \mathrm{E}$ metodom $\mathrm{i}$

\section{REFERENCES}

1. Ross M, Pawlina W. Histology: a text and atlas 5ed. New York:Lippincot Williams and Wilkins, 2006.

2. Nurmenniemi PK, Pernu HE, Knuuttila ML. Mitotic activity of keratinocytes in nifedipine- and immunosuppressive medication-induced gingival overgrowth. J Periodontol. 2001;72(2): 167-73.

3. Kim JM, Bak EJ, Chang JY, et al. Effects of HB-EGF and epiregulin on wound healing of gingival cells in vitro. Oral Dis. 2011; 17(8): 785-93.

4. Chapple IL, Van der Weijden F, Doerfer C, et al. Primary prevention of periodontitis: managing gingivitis. J Clin Periodontol. 2015; Suppl 16: S71-6.

5. Petersen PE, Bourgeois D, Ogawa H, Estupinan-Day S, Ndiaye C. The global burden of oral disease and risk to oral health. Bull World Health Organ. 2005; 83(9): 661-9. imunohemijskom metodom uz upotrebu anti-Ki-67 i anti-CD79a antitela. Morfometrijsko merenje i analiza slika histoloških preparata je obavljena uz pomoć Image Pro Plus softvera (Media Cybernetics, USA) i Axiovision (Ziess, USA) programa za obradu slike.

Rezultati: Naše istraživanje je pokazalo da udaljena inflamacija izaziva zadebljanje epitela slobodne gingive i to proporcionalno težini zapaljenskog procesa. Raste $\mathrm{u}$ istom smislu i mitotski indeks bazalnih keratinocita (do 132\%), kao i dužina bazalne lamine (do 70\%).

Zaključak: Utvrđivanje debljine slobodnog gingivalnog epitela je dobar pokazatelj uznapredovalosti inflamatornog procesa gingive.

Ključne reči: histomorfometrija, gingiva, Ki-67, gingivitis.

6. Beltrán-Aguilar ED, Eke PI, Thornton-Evans G, Petersen PE. Recording and surveillance systems for periodontal diseases. Periodontol 2000. 2012; 60(1): 40-53.

7. Pejcic SA, Zivkovic DV, Bajagic RV, Mirkovic SD. Histological changes of gingival epithelium in smokers and non-smokers. Cent. Eur. J. Med. 2012; 7(6) : 756-60.

8. Villar CC, de Lima AF. Smoking influences on the thickness of marginal gingival epithelium .Pesqui. Odontol. Bras. 2003; 17(1): 41-5.

9. Bulut S, Uslu H, Ozdemir BH, Bulut OE. Analysis of proliferative activity in oral gingival epithelium in immunosuppressive medication induced gingival overgrowth.Head Face Med. 2006;2:13. DOI: 10.1186/1746-160X-2-13.

10. Birajdar SS, Radhika MB, Paremala K, Sudhakara M, Soumya M, Gadivan M. Expression of Ki-67 in normal oral epi- 
thelium, leukoplakic oral epithelium and oral squamous cell carcinoma. J Oral Maxillofac Pathol. 2014; 18(2): 169-76.

11. Yardimci G, Kutlubay Z, Engin B, Tuzun Y. Precancerous lesions of oral mucosa. World J Clin Cases. 2014; 2(12): 866-72.

12. Guiglia R, Musciotto A, Compilato D, et al. Aging and oral health: effects in hard and soft tissues. Curr Pharm Des. 2010; 16(6): 619-30.

13. Prakash P, Rath S, Mukherjee M, et al. Comparative evaluation of the marginal gingival epithelium in smokers and nonsmokers: a histomorphometric and immunohistochemical study. Int J Periodontics Restorative Dent. 2014; 34(6): 781-6.

14. Lukandu OM. Differential changes in epithelial thickness of oral and pathological odontogenic epithelia in response to inflammatory cell infiltrate. International Journal of Advanced Research. 2015; 3(11): 536-43.

15. Prestin S, Rothschild SI, Betz CS, Kraft M. Measurement of epithelial thickness within the oral cavity using optical coherence tomography. Head Neck. 2012; 34(12): 1777-81.

\section{Correspondence to / Autor za korespondenciju}

Prof. Dr Zoran Milosavljevic

Faculty of Medical Sciences Kragujevac

Institute for Histology and Embryology

Svetozara Markovića 69

34000 Kragujevac, SERBIA

Phone: +381 641247461,

Fax: +38134306800,

E-mail: zormil67@medf.kg.ac.rs 